\title{
Construction and demolition waste management in Korea: recycled aggregate and its application
}

\author{
Jeonghyun $\operatorname{Kim}^{1}$ (D)
}

Received: 25 April 2021 / Accepted: 19 July 2021 / Published online: 28 July 2021

(C) The Author(s) 2021

\begin{abstract}
Construction and demolition waste generated in the Republic of Korea accounts for about half of the annual waste. The generation of construction waste is expected to increase gradually due to obsolete structures and reconstructions that have reached the end of their service life. Considering the geographical characteristics of Korea, where the land area is small and about $70 \%$ of which is mountainous, landfilling of waste is absolutely limited. Therefore, resource circulation such as recycling of construction waste is an urgent and important task. This paper overviews the current status of construction waste generation, treatment, and the flow of government policies in Korea. Furthermore, the current status, limitations, and stakeholder efforts regarding recycling of recycled aggregate from construction waste were reviewed. Data used in this paper were mostly collected from government reports, construction waste regulations, and research papers. The results show that construction waste management systems have been enacted and revised in line with social needs, and each stakeholder is making an effort to use the construction waste practically. The findings can provide valuable examples for countries that lack construction waste management systems.
\end{abstract}

\section{Graphic abstract}
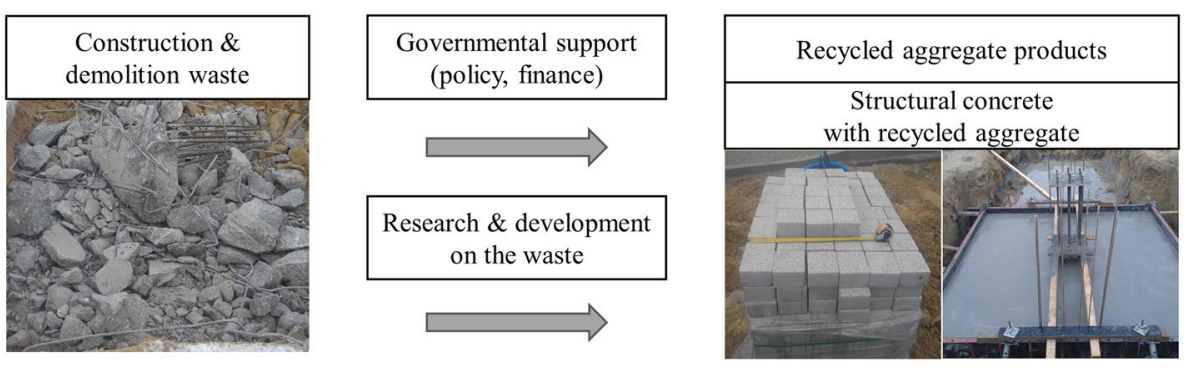

Keywords Construction waste $\cdot$ Recycling $\cdot$ Recycled aggregate $\cdot$ Resource circulation $\cdot$ Waste management

\section{Introduction}

The land area of the Republic of Korea is $99,720 \mathrm{~km}^{2}$, which is only the 109th in the world, but it is 28 th in population with about 51 million people. This is the most densely populated country among OECD members (CIA 2020; OECD

Jeonghyun Kim

jeonghyun.kim@pwr.edu.pl

1 Faculty of Civil Engineering, Wrocław University of Science and Technology, Wybrzeże Wyspiańskiego 27, 50-370 Wroclaw, Poland
2015). Moreover, in Korea, where mountainous areas occupy about $70 \%$ of the land area, most of the population lives densely in urban areas. Therefore, a series of demolition work inevitably occurs continuously. Civil and building constructions are expected to steadily increase, and in exchange, construction and demolition (C\&D) waste is also expected to increase due to the dismantling of old infrastructures and reconstructions (Lee et al. 2013).

Improper disposal of waste occurs quite frequently in Korean society. Some construction companies illegally dump waste into nature. Some others rent empty warehouses 
and fill them with waste and then run away (ME 2019a). These dumped wastes are separated, sorted, and recycled, but in the end, all of these activities result in waste of the national budget. As of $2016,52 \%$ of 474.6 million $\mathrm{m}^{3}$ of the nationwide landfill capacity was already filled with waste (ME 2017). The Sudokwon Landfill Management Corporation announced that the direct import of $C \& D$ waste to the landfill sites in the metropolitan area will be prohibited as of 2022. Thus, only the remaining C\&D waste that has undergone the recycling process at recycling plants can be brought in. This policy is expected to reduce the amount of C\&D waste brought into the landfill sites to 751 thousand tons by 2025 , which is about $52 \%$ of the amount of C\&D waste imported in 2019. Therefore, establishing a resource circulation system through maximizing waste recycling is an urgent and important task for the transition to a sustainable society.

As Korean society achieved rapid economic growth, industrialization, and urbanization in the 1970s, waste became a social issue, but there was no proper waste management system. With the Waste Control Act in 1986, the waste management policies have been enacted and revised based on economic development and social changes (Yang et al. 2015). Figure 1 represents the flow of policies on waste management from the 1980 s to the present. In the 1980 s and 1990s, the policies focused on safe disposal. As the Act on the Promotion of Saving and Recycling of Resources came into effect in 1992, regulations on the use of packaging materials and disposable products, and policies to foster the recycling industry were implemented. In 1995, the Promotion of Installation of Waste Disposal Facilities and Assistance to Adjacent Areas Act was enacted to resolve the opposition of the local residents caused by the installation of waste disposal facilities through the provision of various convenience facilities. In 2003, the Construction Waste Recycling Promotion Act was enacted, laying the foundation for the recycling of construction waste. In 2007, the concept of resource circulation was introduced. In 2016, the Act on Resource Circulation was established with the vision of realizing a sustainable economic circulation through a virtuous cycle of resources. The Act differs from existing waste management policies in terms of policy background, purpose, and strategy (Table 1). The main concept is resources, not waste. Also, the focus is on efficient production and consumption of national resources rather than on the unconditional reduction of waste (ME 2019b).

Similar to other countries, the major components of C\&D waste generated in Korea are concrete and asphalt. Hence, research and development $(R \& D)$ related to the recycling of $C \& D$ waste has been carried out in the direction of

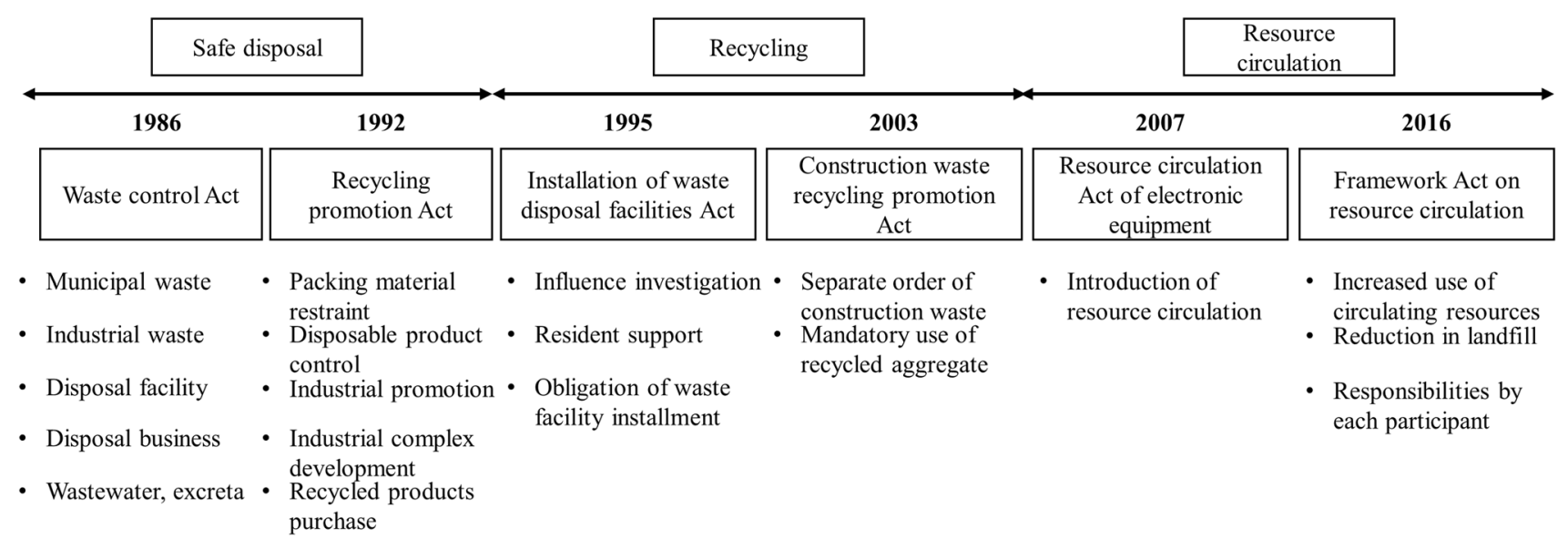

Fig. 1 Flow of waste management policies (ME 2019b)

Table 1 The paradigm shift in waste management policies (ME 2019b)

\begin{tabular}{lll}
\hline- & Existing policies & Framework Act on resource circulation \\
\hline Background & Environmental pollution by waste & Climate change, depletion of raw materials and energy \\
Objectives & Creating a pleasant living environment & Establishing resource circulation society \\
Key concept & Waste & Resource \\
$\begin{array}{l}\text { Strategy } \\
\text { Main task }\end{array}$ & $\begin{array}{l}\text { Reduce-recycle-disposal } \\
\text { Volume-based waste fee system, installment of } \\
\text { disposal facilities }\end{array}$ & $\begin{array}{c}\text { Sustainable development, Quality Certification of recycled products, } \\
\text { energy recovery from waste }\end{array}$ \\
\hline
\end{tabular}


producing high-quality recycled aggregate from concrete and asphalt waste (Kim \& Chung 2012). As a result of the $\mathrm{R} \& \mathrm{D}$, the quality of the products made with recycled aggregate has improved to a level comparable to that of products with natural aggregate (Fathifazl et al. 2009; Tam and Tam 2007). However, the use of recycled aggregate is more influenced by external factors than the quality of the recycled aggregate product itself. This mainly includes the shortage of detailed guidelines for the recycling of $C \& D$ waste and negative perceptions of stakeholders.

The generation, treatment, and utilization of $C \& D$ waste is a frequently discussed topic and a survival strategy for the sustainable development in the construction sector. Although many research and review papers have been published on this topic from a global perspective (Gálvez-Martos et al. 2018; Karunasena et al. 2009; Lu and Yuan 2010; Yeheyis et al. 2013), there are still gaps in them that need to be addressed. The main research gap is the lack of a comprehensive review of C\&D waste management and utilization in Korea. Hence, due to the lack of data, some researchers who have difficulty accessing data written in Korean refer to out-of-date information written in English that have already been withdrawn or are no longer valid. This is because government publications and regulations are mainly available in Korean only. Therefore, this study aims to review the current status of C\&D waste generation and disposal, policies on $\mathrm{C} \& \mathrm{D}$ waste management. It also includes the recent production status, specifications of recycled aggregate, environmental impacts, barriers to using the recycled aggregate, and practical application cases. This review paper can be a useful reference for other research on construction waste management.

\section{Methods}

The research methods were established based on the following questions: (i) What is the current status of construction waste management? (ii) What are the existing construction waste policies? (iii) How is recycled aggregate being utilized? (iv) What are the policy contributions and limitations of the use of recycled aggregates?

For the policies and status quo on $C \& D$ waste in Korea, data were collected from reports published on the official websites of each government agency. For data search on the status of recycled aggregate production and utilization, environmental impact, and limitations, the Web of Science and KoreaScience were used as databases. KoreaScience is an open platform for Korean academic publications in science and technology. The search keywords were construction waste, construction waste management, and recycled aggregate utilization. As Korea is a non-English-speaking country, government reports are often only available in
Korean. Therefore, both Korean literature and English literature were included in this research. As issues in the field change rapidly, only documents published in the twenty-first century were included. The literature retrieved from both databases was screened by checking the titles and abstracts in the initial screening. In particular, research articles on $\mathrm{C} \& \mathrm{D}$ waste management policies, the facility status, and utilization of recycled aggregate were focused, and studies on the mechanical and durability properties of cement composites using recycled aggregate were removed from the literature sample.

In order to answer the above questions, based on the collected literature, the recent $C \& D$ waste generation status in Korea and government policies are summarized in chronological order in "Construction and demolition waste" section. Next, the current status of recycling facilities for concrete waste, the major component of C\&D waste, is summarized "Status of recycled aggregate production facility" Section, and the requirements specified in various normative documents for the use of recycled aggregate generated from concrete waste as a construction material are described "Specification for recycled aggregates" section. "Environmental benefits of using recycled aggregates" and " Barriers to the use of recycled aggregates" section address the environmental benefits of recycled aggregate and the barriers to its use. These sections include case studies conducted in the Korean context. "Recycled aggregate applications" section addresses the efforts of each party for the utilization and the practical application of recycled aggregate in the construction industry. "Conclusions" section presents the conclusions of this study.

\section{Construction and demolition waste}

\section{Status of construction and demolition waste}

From 2009 to 2019, C\&D waste generated in Korea has gradually increased due to the reconstructions and deteriorated infrastructures, accounting for $45.9-51.2 \%$ of the total annual waste except for designated waste (Fig. 2). $\mathrm{C} \& \mathrm{D}$ waste in Korea is primarily classified into combustible, noncombustible, combustible, and noncombustible mix, and others, and the C\&D waste is subdivided into 18 groups as below. The largest portion of the $C \& D$ waste is concrete waste $(60.8-65 \%)$. Asphalt waste accounts for the second largest share with $17.6-19.3 \%$, followed by mixed construction waste (11\%), soil and stones $(4 \%)$, and bricks (2\%) (KOSIS, 2020a).

- Combustible: timber, synthetic resin, fiber, wallpaper

- Noncombustible: concrete, asphalt, brick, block, roofing, soil and stones, sludge, metal, glass, tile, ceramic 


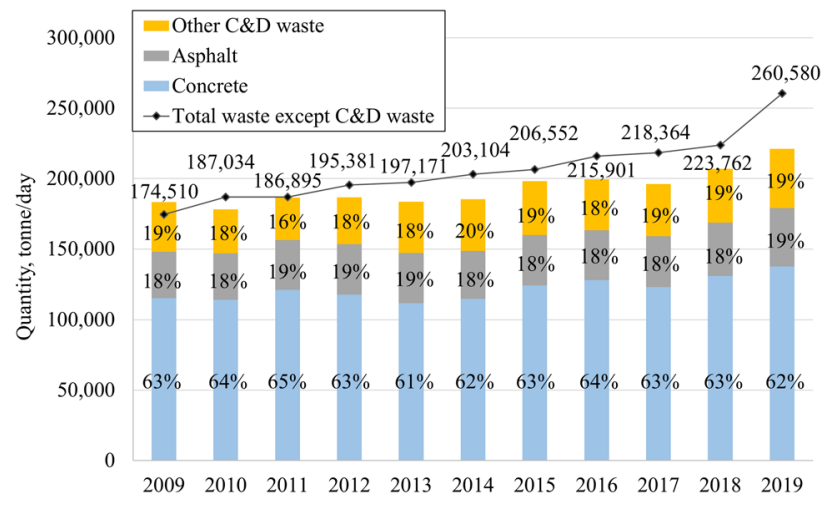

Fig. 2 Annual C\&D waste generation in Korea (KOSIS 2020a)

- Combustible and noncombustible mixed: board, panel, mix C\&D waste

- Others

During the same period, the recycling rate of major C\&D waste is as follows: concrete (99.64-99.99\%), asphalt (99.88-100\%), masonry (97.93-99.99\%), and soil and stones $(85.10-99.84 \%)$ (KOSIS 2020b). The use of these construction wastes is covered in the following chapters. According to the study by Tam et al. (2018), the C\&D recovery rates of neighboring countries, Japan, China, and Taiwan are $80.5 \%, 40 \%$, and $91 \%$, respectively. Thus, numerically, the C\&D waste in Korea seems to be recycled well. However, comparisons of numbers may not be appropriate, as each country may have different methods of measuring recycling rates. For example, under the Construction Waste Recycling Promotion Act, less than 5 tons of waste generated at construction sites is not classified as construction waste. Moreover, since the recycling rate is calculated based on the amount of $C \& D$ waste brought into the recycling plants, the rate does not represent the actual recycling rate (Park 2017). Some small recycling companies go bankrupt with waste left behind. If these abandoned wastes were not discovered in advance, the waste may have been considered recycled in statistics.

\section{Acts on construction and demolition waste}

Policies and regulations on C\&D waste management in Korea began to be enacted, implemented and revised in the $2000 \mathrm{~s}$.

In 2001, a separate contract system for C\&D waste was implemented. For construction works with more than 100 tons of $C \& D$ waste ordered by the government or local governments, the construction works and C\&D waste disposal services shall be ordered separately (ME 2001). Therefore, the orderer should reflect a reasonable cost for $C \& D$ waste disposal at the design stage based on the expected amount of the $\mathrm{C} \& \mathrm{D}$ waste to be generated during the construction project. The system guaranteed the independence and income of recycling companies, contributing to the investment in $R \& D$ and equipment for efficient recycling (Lee and Lee 2014).

In 2003, the Construction Waste Recycling Promotion Act was enacted for the purpose of efficient use of national resources by promoting the recycling of $C \& D$ waste. In 2005, the year the Act was enforced, the C\&D waste amounted to 2.7 million tons, exceeding $50 \%$ of the total landfill waste of 4.8 million tons that year, but gradually decreased to $25 \%$ of 3.7 million tons of total landfill waste in 2018 (SLC 2019).

In 2006 and 2011, the first and second Master Plans for Recycling Construction Waste for the next five years were established, suggesting mid-to-long-term objectives for efficient use of resources, suppression of waste generation, and promotion of the use of recycled materials (ME 2006, 2011). In 2016, under the Framework Act on Resource Circulation, the existing Framework Plan for Resource Circulation, National Plan for Waste Management, and Master Plan for Construction Waste Recycling have been integrated into a Master Plan of Resource Circulation (ME 2018) (Table 2). These plans particularly include the mandatory use of recycled aggregate, which is related to the fact that concrete waste accounts for a significant portion of $C \& D$ waste, as mentioned above. Complying with the Construction Waste Recycling Promotion Act, construction projects ordered by the government, local governments, or any of the following institutes are obligated to use recycled aggregate:

- Public institutions pursuant to the Act on the Management of Public Institutions

- Government-funded research institutes according to the Act on the Establishment, Operation and Fostering of Government-Funded Science and Technology Research Institutes, etc.

- Government-funded research institutes in science and technology pursuant to the Act on the Establishment, Operation and Fostering of Government-Funded Science and Technology Research Institutes, etc.

- Public enterprises under Special Acts

- Local public corporations pursuant to the Local Public Enterprises Act

- Implementers pursuant to the Act on Private Participation in Infrastructure

In 2019, a clause on the separate dismantlement was newly added to the Act. As of April 2021, demolition works with a certain structure and size ordered by the government and public institutions shall first dismantle certain wastes to prevent the mixing of recyclable and non-recyclable wastes. Park et al. (2013) noted that the separate dismantlement is expected to increase cost due to the longer work periods and 
Table 2 Overview of the master plans for C\&D waste recycling

\begin{tabular}{|c|c|c|c|}
\hline- & $\begin{array}{l}\text { First master plan for recycling con- } \\
\text { struction waste }\end{array}$ & $\begin{array}{l}\text { Second master plan for recycling } \\
\text { construction waste }\end{array}$ & First master plan for resource circulation \\
\hline Duration & $2007-2011$ & 2012-2016 & $2018-2027$ \\
\hline Objectives & $\begin{array}{l}\text { Eco-friendly disposal and promotion } \\
\text { of recycling of C\&D waste }\end{array}$ & $\begin{array}{l}\text { Ecological environmental preserva- } \\
\text { tion and enhancement of resource } \\
\text { circulation infrastructure }\end{array}$ & $\begin{array}{l}\text { Realization of a sustainable circular } \\
\text { economy through a virtuous cycle of } \\
\text { resources }\end{array}$ \\
\hline Strategy & $\begin{array}{l}\text { 1. Improvement in the actual use of } \\
\text { recycled aggregate } \\
\text { 2. Reduction in waste generation } \\
\text { 3. Appropriate disposal of C\&D waste }\end{array}$ & $\begin{array}{l}\text { 1. Reduction in waste generation } \\
\text { 2. Environmental preservation and } \\
\text { strengthening of resource circulation } \\
\text { 3. Establishment of C\&D waste man- } \\
\text { agement policy and infrastructure }\end{array}$ & $\begin{array}{l}\text { 1. Establishment of a resource circula- } \\
\text { tion system (production-consump- } \\
\text { tion-management-recycling) } \\
\text { 2. Prioritizing waste reduction, promo- } \\
\text { tion of high-quality material recycling } \\
\text { 3. Optimization of waste management } \\
\text { by region based on public participa- } \\
\text { tion governance }\end{array}$ \\
\hline $\begin{array}{l}\text { Mandatory use } \\
\text { rate of recycled } \\
\text { aggregate }\end{array}$ & $30 \%$ & $45 \%$ & $50-55 \%$ \\
\hline
\end{tabular}

more needed manpower than traditional dismantling work; however, the enhanced efficiency of C\&D waste recycling can offset this to some extent.

\section{Recycled aggregate}

\section{Status of recycled aggregate production facility}

Recycled aggregates are obtained by crushing concrete waste in C\&D waste. Unlike natural aggregates, the recycled aggregates are likely to contain various foreign substances, and old mortar is adhered to the surface of aggregates, resulting in a large quality deviation (Kim et al. 2019). Therefore, R\&D in the production of recycled aggregates means obtaining the recycled aggregates with uniform quality from C\&D waste in an economical manner. The C\&D waste can be processed at construction or demolition sites by mobile crushers and at recycling plants with stationary crushing facilities. Obtaining recycled aggregates on-site can reduce initial investment for equipment and production costs, but the ability to remove impurities is less effective. On the other hand, processing C\&D waste at recycling plants results in higher initial investment in the facility, but can produce high-quality recycled aggregates (Silva et al. 2017).

Kim et al. (2004) surveyed 100 recycling companies over the recycling facilities. Regarding the type of concrete crusher, 55 companies responded that jaw crusher is used in the primary crushing, and 16 companies were surveyed to use a cone crusher. Secondary crushing was also the highest in the order of jaw crusher, cone crusher, and impact crusher. In the third crushing process, the cone crusher was widely used, and some recycling companies replied that roll crushers and roller mills are used to produce fine-size recycled aggregates. For screening, the first sorting is basically carried out by manpower to remove bulky debris that is not effective to screen by equipment. For the second screening, air blowing is mainly adopted to get rid of light objects such as plastics, polystyrene. From the third, screenings by manpower, magnetic force, air blowing, washing are used in similar proportions. In particular, washing the produced recycled aggregate is mostly applied from the third screening. Lee et al. (2007a, b) mentioned that most of the recycled aggregate production system is performed by the wet method. Lee (2015) stated that concrete waste mixed with inorganic foreign substances such as bricks and glass should be removed by manpower, which increases production cost, while organic foreign substances such as paper and wood can be removed almost all by using the difference in specific gravity between water and waste. In the production of recycled fine aggregate, a wet method is applied to discharge foreign substances and fine powder, and then, the recycled fine aggregate is used after drying (Lee et al. 2015).

According to KORAS (2020), the first crushed recycled aggregate can be used for covering and backfilling, and the secondary crushed recycled aggregate can be used for the road subbase layer. From tertiary, high-quality recycled aggregate for concrete can be obtained. The schematic representation for recycled aggregate production is shown in Fig. 3.

The C\&D waste recycling market in Korea has been continuously growing. Table 3 shows the status of the crushing facilities of C\&D recycling plants in Korea. From 2013 to 2019 , the number of C\&D waste recycling plants increased from 509 to 587 , and $67.8 \%$ of all the plants consist of three or more crushing processes capable of producing high-quality recycled aggregates. In the same period, the number of recycling plants with more than five cycles of crushing facilities also increased significantly from 48 to 127 . Table 4 presents 
Fig. 3 Schematic representation of recycled aggregate production (KORAS, 2020)

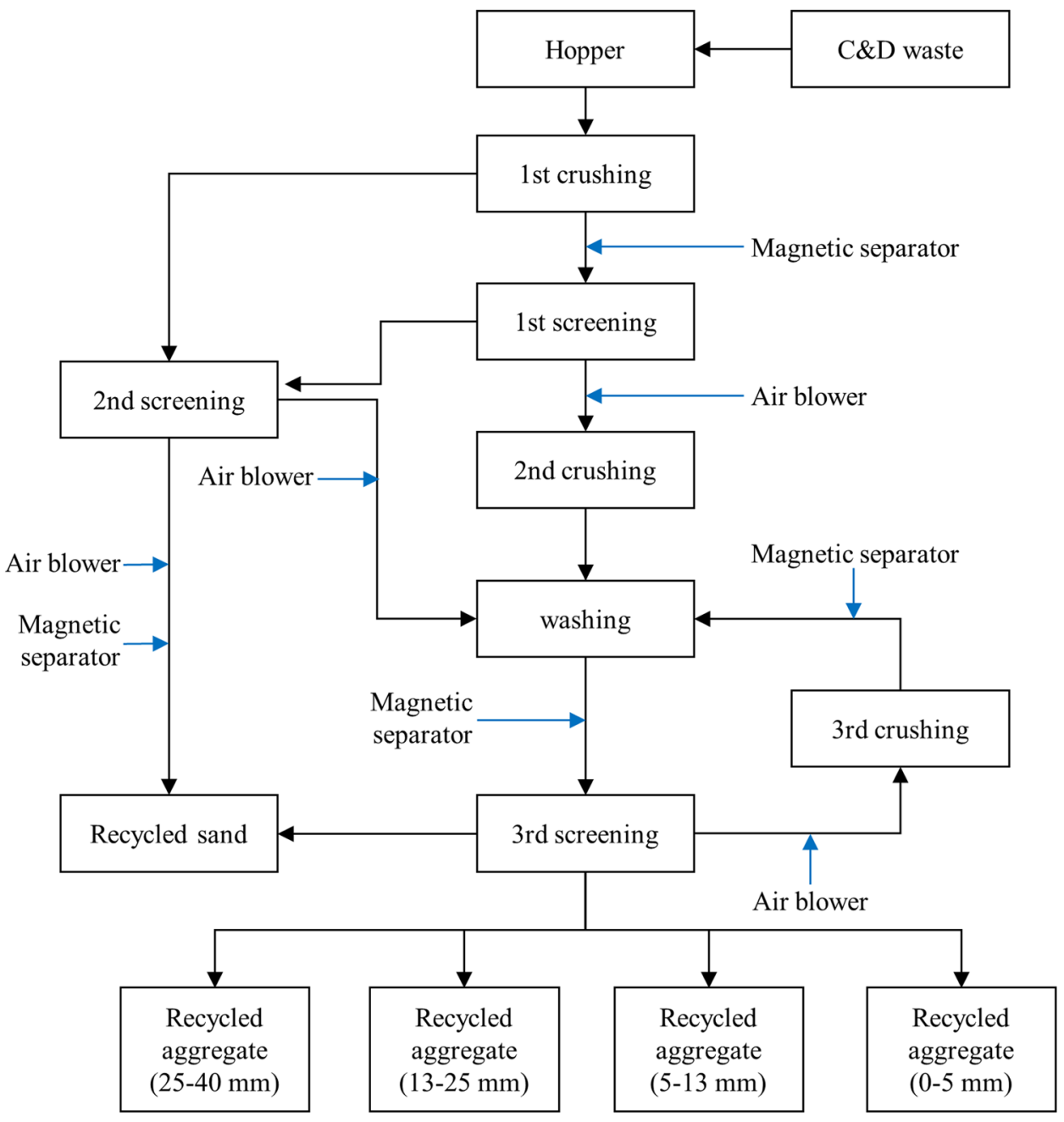

Table 3 Status of crushing facilities in Korea (KORAS 2014, 2015, 2017, 2020)

\begin{tabular}{lllllll}
\hline Year & Primary & Secondary & Tertiary & Quaternary & Quinary & Total \\
\hline 2013 & 40 & 137 & 216 & 68 & 48 & 509 \\
2014 & 41 & 148 & 218 & 65 & 52 & 524 \\
2016 & 46 & 152 & 239 & 68 & 58 & 563 \\
2019 & 52 & 137 & 206 & 65 & 127 & 587 \\
\hline
\end{tabular}

Table 4 Status of quality certification of recycled aggregate based on purpose (KICT 2018, 2020; KORAS 2014, 2015, 2017)

\begin{tabular}{llllll}
\hline Year & $\begin{array}{l}\text { Road } \\
\text { construc- } \\
\text { tion }\end{array}$ & $\begin{array}{l}\text { Coarse } \\
\text { aggregate for } \\
\text { concrete }\end{array}$ & $\begin{array}{l}\text { Fine aggregate } \\
\text { for concrete }\end{array}$ & Asphalt & Total \\
\hline 2014 & 309 & 43 & 27 & 16 & 395 \\
2015 & 319 & 54 & 27 & 17 & 417 \\
2017 & 339 & 75 & 29 & 22 & 465 \\
2018 & 336 & 80 & 28 & 21 & 465 \\
2020 & 359 & 116 & 29 & 21 & 525 \\
\hline
\end{tabular}

the status of quality certification of recycled aggregates from 2014 to 2020. Overall, recycled aggregate for road construction accounts for most of the quality certifications. However, it is worth noting that the number of quality certifications of high-quality recycled aggregates for concrete is increasing every year. 
Table 5 Requirements of recycled aggregates for concrete (KS F2527:2020; MOLIT, 2017)

\begin{tabular}{|c|c|c|c|c|c|c|}
\hline \multirow[t]{2}{*}{ Test } & \multicolumn{2}{|c|}{$\begin{array}{l}\text { Lean concrete } \\
\text { base }\end{array}$} & \multicolumn{4}{|l|}{ Concrete } \\
\hline & RCA & RFA & RCA & RFA & NCA & NFA \\
\hline Max. size, mm & $25-40$ & - & $20-25$ & - & 90 & \\
\hline Min. oven-dry density, $\mathrm{g} / \mathrm{cm}^{3}$ & 2.2 & - & 2.5 & 2.3 & 2.5 & 2.5 \\
\hline Max. absorption, \% & 7 & - & 3 & 4 & 3 & 3 \\
\hline Max. soundness loss, $\%$ & - & 10 & 12 & 10 & 12 & 10 \\
\hline Max. LA abrasion, $\%$ & 50 & - & 40 & - & 40 & - \\
\hline Min. solid content, $\%$ & - & - & 55 & 53 & - & - \\
\hline Max. 0.08 sieve content, $\%$ & & 3 & 1 & 7 & 1 & 5 \\
\hline Max. clay content, $\%$ & 0.25 & 1 & 0.2 & 1 & 0.25 & 1 \\
\hline Alkali-silica reaction & - & - & Innocuous & Innocuous & - & - \\
\hline Max. organic impurities by volume, $\%$ & 1 & 1 & 1 & 1 & - & - \\
\hline Max. inorganic impurities by mass, $\%$ & 1 & 1 & 1 & 1 & - & - \\
\hline
\end{tabular}

$R C A$ recycled coarse aggregate; $R F A$ recycled fine aggregate; $N C A$ natural coarse aggregate; $N F A$ natural fine aggregate
Table 6 Requirements of recycled aggregates for asphalt concrete pavement (KS F2572:2018)

\begin{tabular}{llllll}
\hline Asphalt & $\begin{array}{l}\text { Asphalt } \\
\text { content, \% } \\
\text { penetra- } \\
\text { tion, 25 C, } \\
1 / 10 \mathrm{~mm},\end{array}$ & $\begin{array}{l}\text { 0.08 mm } \\
\text { sieve } \\
\text { amount, } \%\end{array}$ & $\begin{array}{l}\text { Organic } \\
\text { impurities } \\
\text { by vol- } \\
\text { ume, } \%\end{array}$ & $\begin{array}{l}\text { Inorganic } \\
\text { impurities } \\
\text { by mass, } \\
\%\end{array}$ & $\begin{array}{l}\text { Mois- } \\
\text { ture, \% }\end{array}$ \\
\hline Min. 3.8 & Min. 20 & Max. 5 & Max. 1 & Max. 1 & Max. 5 \\
\hline
\end{tabular}

Table 7 Requirements of recycled aggregates for road construction (KS F2574:2018; MOLIT, 2017)

\begin{tabular}{llll}
\hline Test & Road base & Subbase & Backfilling \\
\hline Max. size, mm & $50-75$ & 100 & - \\
Max. LA abrasion, \% & 50 & - & 50 \\
$\begin{array}{l}\text { Max. organic impurities by } \\
\quad \text { volume, } \%\end{array}$ & 1 & 1 & 1 \\
$\begin{array}{l}\text { Max. inorganic impurities by } \\
\quad \text { mass, \% }\end{array}$ & 5 & - & - \\
$\begin{array}{l}\text { Max. plasticity index, \% } \\
\text { Min. modified CBR, \% }\end{array}$ & 6 & 10 & 6 \\
$\begin{array}{l}\text { Min. sand equivalent, \% } \\
\text { Max. liquid limit, \% }\end{array}$ & 30 & 10 & 30 \\
5 mm sieve amount, \% & 25 & - & 25 \\
0.08 mm sieve amount, \% & - & - & 25 \\
\hline
\end{tabular}

\section{Specification for recycled aggregates}

The Quality Standards for Recycled Aggregate (MOLIT 2017) classifies the intended uses of the recycled aggregate, and specifies quality requirements for each application. The requirements of recycled aggregate that can be used for concrete, asphalt, and road construction are shown in Table 5, 6, 7. Table 5 represents the quality requirements of recycled aggregates for lean concrete base and concrete. For comparison, the requirements of natural aggregates for concrete were included. Recycled aggregates for concrete are divided into recycled fine aggregate and recycled coarse aggregate, and require a similar level of physical properties as natural aggregate. Recycled coarse aggregate and recycled fine aggregate shall have an oven-dry density of at least $2.5 \mathrm{~g} / \mathrm{cm}^{3}$ and $2.4 \mathrm{~g} / \mathrm{cm}^{3}$, and the maximum water absorption rate shall be $3 \%$ and $4 \%$, respectively. In addition, recycled aggregates should be innocuous to alkali-silica reactions and the content of foreign substances is limited to a maximum of $1 \%$.

In general, recycled aggregates have a lower density and higher water absorption capacity than that of natural aggregates due to the residual mortar attached to the original aggregates (Yang and Lim 2018); thus, it is virtually impossible to produce high-quality recycled aggregates that meet the requirements with a primary or secondary crushing. However, the number of recycling plants that can produce high-quality recycled aggregate (i.e., certified for quality of recycled aggregates for concrete) is increasing. There is no restriction on the purpose of use; however, the maximum design strength of recycled aggregate concrete should be less than $27 \mathrm{MPa}$, and recycled aggregate cannot be used for special concretes. Regarding the replacement ratio of natural aggregate by recycled aggregate, it is recommended to replace within $60 \%$ by volume when using only recycled coarse aggregate. For recycled fine aggregate, the maximum recommended replacement ratio is $30 \%$. When coarse aggregates and fine aggregates are used together, the recommended replacement ratio is within $30 \%$ of the total aggregate volume.

The maximum size of recycled aggregate for asphalt concrete is $20 \mathrm{~mm}$, and foreign substances such as other 
aggregates, wood, and metal should not be mixed during storage. The storage period is within one year, and if it exceeds one year, it may be used after conducting additional tests.

Recycled aggregates for road construction have different requirements depending on the use of purpose: road base, subsidiary base, and backfill. The road subbase layer serves to distribute traffic loads from the top to the roadbed; thus, the recycled aggregates with sufficient strength and durability should be used to ensure that the load on the roadbed is less than the allowable bearing capacity. Recycled aggregates used as a road base layer have a limitation of 5\% in inorganic foreign matter content compared to other uses.

\section{Environmental benefits of using recycled aggregates}

Concrete, along with steel and cement, is the most widely used material for building construction, accounting for $85 \%$ of total $\mathrm{CO}_{2}$ emissions from the construction of residential apartments in Korea (Jeong et al. 2012). Therefore, several researchers have investigated the environmental benefits of replacing natural aggregate with recycled aggregate tailored to the circumstances in Korea. Kim and Tae (2016) reported that ozone depletion, acidification, abiotic depletion, and eutrophication potential decreased by about 9-29\% when 30\% of natural aggregates were replaced with recycled aggregates. In environmental costs analysis that converts environmental damage into monetary values, Roh et al. (2020) noted that the environmental cost of concrete with natural aggregate was $\$ 6.78 \mathrm{per}^{3}$, whereas that of concrete containing $30 \%$ recycled aggregate was about $13 \%$ cheaper at $\$ 5.88$ per $\mathrm{m}^{3}$. However, the contradictory results have been observed for $\mathrm{CO}_{2}$ emission potentials in life cycle assessments. At 30\% recycled aggregate replacement, Kim and Tae (2016) reported that the use of recycled aggregate increased $\mathrm{CO}_{2}$ emission by $34 \%$ compared to natural aggregate, but in the study of Roh et al. (2020), $\mathrm{CO}_{2}$ emission was $17 \%$ lower than that of natural aggregate. The difference in $\mathrm{CO}_{2}$ emissions may vary depending on which life cycle inventory database is used. It may also relate to the transport of aggregates (Kim et al. 2014).

According to the study performed by Jung et al. (2008), if the transport distance of the material is not taken into account, the amount of $\mathrm{CO}_{2}$ generated in the production of natural aggregate is lower than that in the production of recycled aggregate. However, when aggregates are transported for more than $10 \mathrm{~km}$, the amount of $\mathrm{CO}_{2}$ generated in the production of natural aggregates exceeds that of onsite recycling. In other words, more environmental penalty occurs as the transport distance of aggregates is longer. In this regard, on-site recycling that reuses $C \& D$ waste at the site of generation has been studied.
Jung et al. (2007) conducted an economic analysis of the on-site recycling of concrete waste generated in a large-scale housing development of about 4.7 million $\mathrm{m} 2$. As a result of the analysis, the cost of on-site recycling was found to be $64 \%$ of the plant recycling cost. Sensitivity analysis showed that reduced on-site transport, increase in vehicle speed and volume of concrete waste significantly reduced on-site recycling costs. Therefore, for construction works over a certain size, installing the recycling facilities on construction site is more economical than taking C\&D waste out to the recycling plants for further processing (Lee et al. 2007a, b). The reason for processing of $C \& D$ waste on sites is mainly because the waste transport is the main factor influencing the cost increase, if sorting is carried out at construction sites where waste is generated, the benefits are quite large (Jang et al. 2003). Due to the fact that the content of foreign substances increases during collection, transportation, and storage of C\&D waste, Song et al. (2016) proposed a portable-compact device that can utilize $C \& D$ waste at the building demolition site in urban areas, and verified its effectiveness. Song et al. (2017) stated that C\&D waste generated at construction sites has a high recycling efficiency because the impurity content is small, unlike those generated at the demolition sites. Therefore, from the design stage, waste disposal costs and plans should be estimated to maximize recycling efficiency.

\section{Barriers to the use of recycled aggregates}

It is clear that the $R \& D$ of recycled aggregates has improved the quality of products with properly treated recycled aggregates to a level similar to that of products with natural aggregates (Choi et al. 2018, 2019; Fathifazl et al. 2011; Kim et al. 2016a). However, impurities contained in recycled aggregates cause quality deterioration; thus, if construction wastes can be separated well, a more homogeneous and predictable substitute cement resource can be obtained (Hayles et al. 2018; Kim et al. 2016b). Uneven quality leads to reduced demand and negative perceptions (Jun 2018). Na (2018) stated that there is a negative perception of not only the orderers (i.e., consumers), but also the designers and contractors. Lee (2015) and Yu (2015) argued that the word 'recycled' needs to be deleted from recycled aggregates to dispel negative perceptions. The rationale is that the quality of some natural fine aggregates used for concrete is not superior to that of recycled fine aggregates and that the quality of recycled aggregates certified by recycling companies can be trusted.

One thing to point out is that safety is by far the most important factor in structures. Building the structures involves a substantial amount of investment and time, meaning the magnitude of damage increases if there is a problem with the construction. Thus, some consumers do not want 
their residences to be built from recycled aggregates. The contractors also do not want to take the potential risk of defects in the buildings (Kim et al. 2008). This may be due to the lack of detailed specifications and guidelines that can be applied in the field, although there are frameworks and directions of the government policy on the recycling of construction waste ( $\mathrm{Na} 2018)$.

Oh et al. (2008) mentioned the need for separate dismantlement to maximize the recycling of $C \& D$ waste, and Park et al. (2013) conducted a questionnaire on the separate dismantlement. In the survey research, both parties, the orderers and the demolition companies, formed a consensus on the necessity of the separate dismantlement for efficient recycling of $C \& D$ waste, but the insufficient institutional frameworks were pointed out as the problem. In fact, the separate dismantlement, which will take effect from 2021, has been discussed over the past decade, but could not be enforced due to the lack of detailed guidelines and backlash from the stakeholders (ME 2011).

In addition, various exemption articles hinder the use of recycled aggregate. The conditions for the exemption are as follows (ME 2019c):

- When the quality assurance of construction work is difficult due to the use of recycled aggregate and recycled aggregate products

- When supply and demand recycled aggregate and recycled aggregate, products are difficult due to the regional characteristics such as islands

- When the price of recycled aggregate and recycled aggregate, product is higher than that of other aggregates and products for the same purpose

Jang et al. (2003) mentioned that the problem of the location of $C \& D$ waste facilities should be resolved. It has been mentioned above that transportation of $C \& D$ waste is the factor that has the greatest impact on economic feasibility. Therefore, construction waste facilities should be located within an appropriate distance between the source of supply and the source of demand, but in general, waste facilities face strong resistance from residents from the stage of site selection. As of 2019, the number of construction waste recycling plants in Seoul, which has a population of about 10 million, is only two (KECO 2020).

Moreover, there are the following issues: excessive crackdown by environmental organizations ( $\mathrm{Na} 2018$ ); shortage of waste loading places in construction sites (Jun 2006), moral hazard of waste dischargers (Kim and Chung 2012).

\section{Recycled aggregate applications}

Over the past 10 years, the production of recycled aggregates accounts for $10.9-14.8 \%$ of the total national aggregate

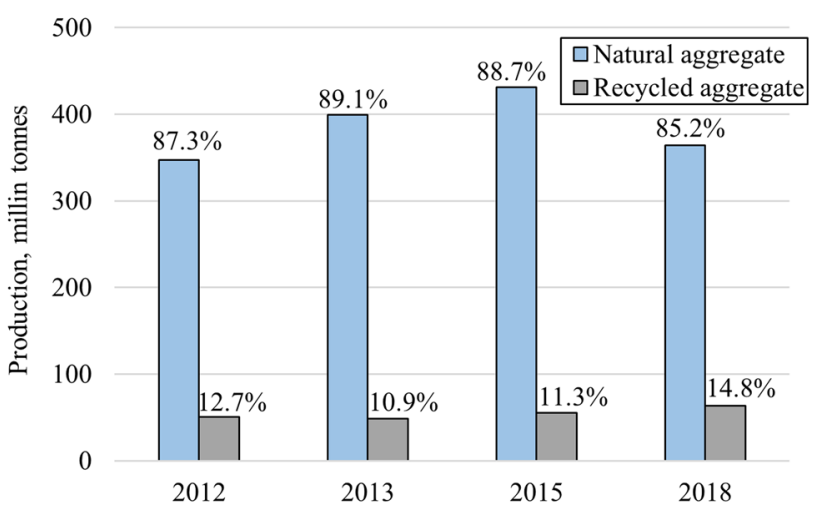

Fig. 4 Annual production of natural aggregate and recycled aggregate in Korea (MOLIT, 2021)

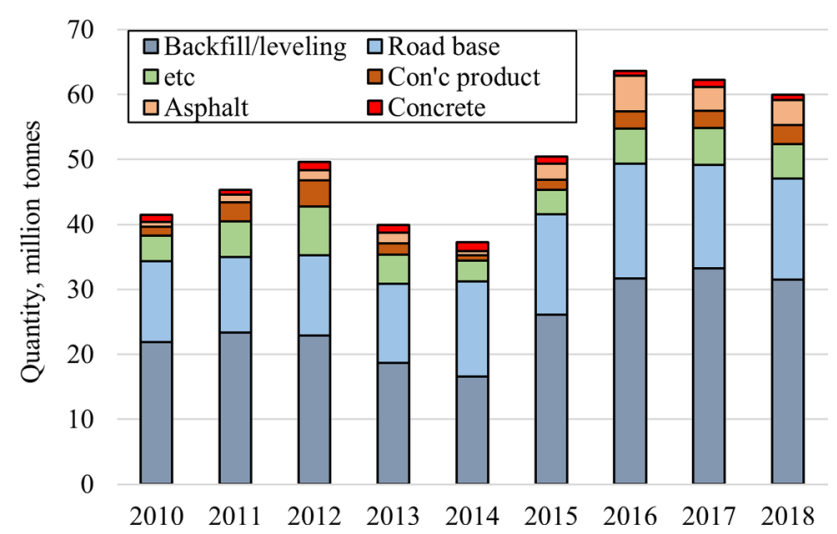

Fig. 5 Use of recycled aggregates by purpose (KORAS, 2014, 2015, 2017, 2020)

production (Fig. 4). The produced recycled aggregates are utilized for various purposes, but most of them are used for backfilling, leveling, and road base. The ratio of C\&D waste recycling plants with tertiary crushing facilities capable of producing high-quality recycled aggregates exceeds $60 \%$ nationwide. However, about $80 \%$ of recycled aggregate is buried in the ground (i.e., backfilling, leveling, road base, subbase), and less than $10 \%$ is used for concrete and asphalt concrete (Fig. 5).

*The data on the amount of the natural aggregates were converted from volume to weight by applying the specific gravity of 2.68

To upcycle recycled aggregate and raise public awareness, the stakeholders are making efforts in their fields. According to the Standard for Utilization of Recycled Building Materials (MOLIT, 2020), when recycled materials are used more than $15 \%, 20 \%$, and $25 \%$ for structural works of a specific building, the floor space index, and height limit 
Table 8 Summary of a demonstration project using 100\% recycled aggregate for concrete structure

\begin{tabular}{|c|c|c|c|}
\hline Date & Purpose & Quantity, $\mathrm{m}^{3}$ & Note \\
\hline 2012.10-2013.2 & Restroom at an expressway service area & 239 & $\begin{array}{l}100 \% \text { of recycled aggregate is used as subbase, lean concrete and } \\
\text { structural concrete }\end{array}$ \\
\hline $2015.01-2015.10$ & Restroom in a national park & 274 & $\begin{array}{l}\text { Secure empirical data on the safety of facilities using recycled } \\
\text { aggregate }\end{array}$ \\
\hline 2015.2-2015.12 & Restroom at an expressway service area & 462 & $\begin{array}{l}\text { Reduced material cost budget by } 13.4 \% \text { through the use of recy- } \\
\text { cled aggregate }\end{array}$ \\
\hline 2014.5-2016.12 & Management office and restroom in a park & 242 & Cost reduction by $4 \%$ compared to natural aggregate concrete \\
\hline
\end{tabular}

of the building can be eased by $5 \%, 10 \%$, and $15 \%$, respectively. Moreover, the Korean government implemented demonstration projects to build concrete structures with $100 \%$ of recycled aggregate (Table 8). In 2013, a public restroom at an expressway service area using $100 \%$ recycled aggregate concrete was completed. This project not only reduced construction costs by replacing natural aggregate with recycled aggregates, but it was also an opportunity to improve public negative perceptions of recycled aggregates. Other concrete buildings were completed in 2015 and 2016 successively, which are expected to become the scientific and technical basis for the use of recycled aggregate as structural concrete after continuous monitoring (KORAS 2014, 2015, 2017). According to the Master Plan of Resource Circulation (ME, 2018), the demonstration project to build structures using $100 \%$ recycled aggregate will be expanded to ensure quality and stability. With the accumulated data, the mandatory use rate of recycled aggregates is planned to gradually increase.

Researchers have tried to put construction waste into practical use. Wi et al. (2011) analyzed the physical and thermal properties of recycled aggregate to use it as a backfill material for transmission and distribution pipeline. Kim et al. (2018) fabricated rainwater storage blocks to mitigate the urban heat island effect by utilizing recycled aggregate powder generated during the production of recycled aggregate from concrete waste.

Since 2010, the Ministry of Environment, Ministry of Land, Infrastructure and Transport, and Korea Resource Recycling Association have held annual competitions for the use of recycled aggregates and recycled aggregate products, encouraging the use of recycled aggregates by private construction companies as well as national institutions.

\section{Conclusions}

This paper reviews the recent policies on construction and demolition waste management, the current status of recycled aggregate production facilities, and the actual use of recycled aggregate in the Republic of Korea.

C\&D waste management systems in Korea have been continuously enacted and revised under the circumstances of Korean society, preparing for a transition to a resource circulation society. Statistical systems for C\&D waste generation and recycling appear to be well established. The government is putting a lot of effort into promoting the recycling of construction waste. This includes pilot projects for road pavement and building construction using recycled aggregate. These efforts contribute to raising awareness of recycled aggregates and efficient use of national resources.

The number of recycling plants that produce high-quality recycled aggregates for concrete and the number of quality certifications of recycled aggregates for concrete are gradually increasing. Thus, the quality of recycled aggregates is no longer a major factor limiting the widespread use. However, negative public perceptions caused by the use of incompletely treated recycled aggregate and illegal dumping of construction waste still remain a problem. Furthermore, the lack of detailed specifications of recycled aggregate products is a frequently mentioned obstacle among construction practitioners and is one of the factors that hinder the upcycling of recycled aggregates.

Although the recycling rate of $C \& D$ waste in Korea exceeds $90 \%$, it may not be appropriate to directly compare statistics by country due to differences in the criteria for calculating statistics. In addition, studies on the long-term mechanical properties and durability performance of recycled aggregate concrete structures built through the government pilot project should be conducted.

Only a small number of laws and regulations are provided in English, but various guidelines, detailed status and specifications are mostly provided in Korean. Also, the frequency of revision is high in keeping with the rapidly changing society. Such information is not practically accessible unless the searcher is fluent in the language. Thus, the author has tried to include the latest data as possible in this review paper. This study can serve as an important basis for other researchers in the field. In particular, the relaxation of the height restriction of buildings when using $C \& D$ waste and the pilot projects for concrete structure with $100 \%$ recycled aggregate reviewed in this study can be provided as useful models in countries where the $\mathrm{C} \& \mathrm{D}$ waste management systems are relatively poorly established. 
Funding Not applicable.

\section{Declarations}

Conflicts of interests The authors declare that they have no conflict of interest.

Open Access This article is licensed under a Creative Commons Attribution 4.0 International License, which permits use, sharing, adaptation, distribution and reproduction in any medium or format, as long as you give appropriate credit to the original author(s) and the source, provide a link to the Creative Commons licence, and indicate if changes were made. The images or other third party material in this article are included in the article's Creative Commons licence, unless indicated otherwise in a credit line to the material. If material is not included in the article's Creative Commons licence and your intended use is not permitted by statutory regulation or exceeds the permitted use, you will need to obtain permission directly from the copyright holder. To view a copy of this licence, visit http://creativecommons.org/licenses/by/4.0/.

\section{References}

Choi W-Y, Kim S-H, Lee S-H, Jeon C-S (2019) A study on the strength properties and life cycle assessment of recycled fine aggregate concrete. J Korean Recycl Constr Resour Inst 7:123-130

Choi W-Y, Lee S-H, Jun C-S, Kim T-H (2018) A study on the strength properties and life cycle assessment of high strength concrete using recycled coarse aggregate. J Korean Recycl Constr Resour Inst 6:8-15

CIA, 2020, The World Factbook, Central Intelligence Agency. https:// www.cia.gov/the-world-factbook/countries/korea-south/ Accessed 25 April 2021

Fathifazl G, Abbas A, Razaqpur AG, Isgor OB, Fournier B, Foo S (2009) New mixture proportioning method for concrete made with coarse recycled concrete aggregate. J Mater Civ Eng 21(10):601611. https://doi.org/10.1061/(ASCE)0899-1561(2009)21:10(601)

Fathifazl G, Ghani Razaqpur A, Burkan Isgor O, Abbas A, Fournier B, Foo S (2011) Creep and drying shrinkage characteristics of concrete produced with coarse recycled concrete aggregate. Cem Concr Compos 33(10):1026-1037. https://doi.org/10.1016/j. cemconcomp.2011.08.004

Gálvez-Martos JL, Styles D, Schoenberger H, Zeschmar-Lahl B (2018) Construction and demolition waste best management practice in Europe. Resour Conserv Recycl 136:166-178. https://doi.org/10. 1016/j.resconrec.2018.04.016

Hayles M, Sanchez LFM, Noël M (2018) Eco-efficient low cement recycled concrete aggregate mixtures for structural applications. Constr Build Mater 169:724-732. https://doi.org/10.1016/j.conbu ildmat.2018.02.127

Roh S, Kim R, Park W-J, Ban H (2020) Environmental evaluation of concrete containing recycled and by-product aggregates based on life cycle assessment. Appl Sci. https://doi.org/10.3390/app10 217503

Jang J-M, Choi H-B, Kang K-I (2003) A study on the method applying construction wastes of construction in Korea. J Korea Inst Build Constr 3(1): 147-154

Jeong YS, Lee SE, Huh JH (2012) Estimation of CO 2 emission of apartment buildings due to major construction materials in the Republic of Korea. Energy Build 49:437-442. https://doi.org/10. 1016/j.enbuild.2012.02.041
Jun MH (2006) Generation and recycling of construction waste, suggestions for revitalizing the use of recycled aggregate in the public sector. J Korean Geo-Environ Soc 7(3):42-48

Jun MH (2018) Suggestions for revitalizing the use of recycled aggregate in the public sector. J Rec Const Resources 13(2):33-38

Jung J-S, Lee J-S, An Y-J, Lee K-H, Bae K-S, Jun M-H (2008) An analysis of emission of carbon dioxide from recycling of waste concrete. Archit Inst Korea 24:109-116

Jung J-S, Lee J-S, Jo W-C, Jun M-H, Lee D-H, Bang J-D (2007) The development of economical index for site recycling of waste concrete-a case study at hosing development district. Korean J Constr Eng Manag 8(4):146-154

Karunasena G, Amaratunga D, Haigh R, Lill I (2009) Post disaster waste management strategies in developing countries: case of Sri Lanka. Int J Strateg Prop Manag 13(2):190

KECO, 2020 Report on waste recycling performance and facilities, Korea Environment Corporation.

KICT, 2018, The status of quality certification of recycled aggregate, Korea Institute of Civil Engineering and Building Technology.

KICT, 2020, The status of quality certification of recycled aggregate, Korea Institute of Civil Engineering and Building Technology.

Kim H-K, Kim Y-A, Choi S-Y, Cho Y-K (2018) Evaluation of rainwater storage block using recycled aggregate by-product. J Korean Recycl Constr Resour Inst 6:167-173

Kim J-M, Kim J-H, Cha H-S, Shin D-W (2008) Disposal process improvement of construction waste through identifying factors obstructing reduction and recycle of construction wastes. Korean J Constr Eng Manag 9(1):77-86

Kim J-H, Tae S-H, Song H, Shin H-U (2016a) Theoretical Proposal for the mix design of recycled cement utilizing inorganic construction wastes. J Rec Const Resour 4(3):250-258

Kim J-H, Sung J-H, Jeon C-S, Lee S-H, Kim H-S (2019) A Study on the properties of recycled aggregate concrete and its production facilities. Appl Sci 9:1935

Kim N, Kim J, Yang S (2016b) Mechanical strength properties of RCA concrete made by a modified EMV method. Sustainability 8(9):1-15. https://doi.org/10.3390/su8090924

Kim T, Tae S (2016) Proposal of environmental impact assessment method for concrete in South Korea: an application in LCA (life cycle assessment). Int J Environ Res Public Health. https://doi. org/10.3390/ijerph13111074

Kim TH, Cha GW, Hong WH (2014) A study on the potential of co emissions reduction recycled aggregate according to transportation plan of waste concrete - focused on Daegu City and Kyungpook Area. KIEAE J 1:331-338

Kim Y, Chung M-H (2012) Study on the recycling of the construction wastes and reformation of the system. J Korea Org Resour 20(2):27-35

Kim YS, Jun SC, Lee SH (2005) A study on analysis of production and facility status of recycled aggregates, Proceedings of Archit Inst Korea Struct Constr, Seoul, KOREA, 25(1):97-100

KORAS, 2014 Casebook of recycled aggregate and recycled aggregate product, Korea Resource Recycling Association.

KORAS, 2015, Casebook of recycled aggregate and recycled aggregate product, Korea Resource Recycling Association.

KORAS, 2017, Casebook of recycled aggregate and recycled aggregate product, Korea Resource Recycling Association.

KORAS, 2020, Casebook of recycled aggregate and recycled aggregate product, Korea Resource Recycling Association.

KOSIS, 2020a, Status of national waste generation, Korea Statistical Information Service. https://kosis.kr/statHtml/statHtml.do?orgId= 106\&tblId=DT_106N_99_3300306\&conn_path=I2 Accessed 25 April 2021

KOSIS, 2020b, Status of national waste disposal, Korea Statistical Information Service. https://kosis.kr/statHtml/statHtml.do?orgId= 
106\&tblId=DT_106N_99_3300316\&conn_path=I2 Accessed 25 April 2021

Lee D-H, Kim H-J, Jun M-H, Jung J-S (2007a) The State of the art report on technical development of recycled aggregates for concrete. J Korea Concr Inst 19(2):34-41

Lee G-C (2015) Theme and prospect of practical use of recycled aggregates for concrete. J Rec Const Resources 10(3):12-14

Lee J-H, Lee C-G, Ki H-H (2015) Separation technologies of foreign materials in construction wastes. J Rec Const Resources 10(3):15-21

Lee JW, Kwak KH, Shin SH, Kim KH (2007b) An economic analysis of disposing waste concrete; processing on commision, site recycling, mobile crusher. Proceedings of Korean J Constr Eng Manag 1:408-411

Lee S, Park W, Lee H (2013) Life cycle CO2 assessment method for concrete using $\mathrm{CO} 2$ balance and suggestion to decrease LCCO2 of concrete in South-Korean apartment. Energy Build 58:93-102. https://doi.org/10.1016/j.enbuild.2012.11.034

Lee W-P, Lee C-H (2014) Construction waste recycling policy and system status. J Rec Const Resources 9(1):10-18

Lu W, Yuan H (2010) Exploring critical success factors for waste management in construction projects of China. Resour Conserv Recycl 55(2):201-208. https://doi.org/10.1016/j.resconrec.2010.09.010

ME, 2001, Guideline for disposal of construction waste, Ministry of Environment.

ME, 2006, The first master plan for construction waste recycling, Ministry of Environment.

ME, 2011, The second master plan for construction waste recycling, Ministry of Environment.

ME, 2017, Survey on Waste Materials, Ministry of Environment.

ME, 2018, The first master plan of resource circulation, Ministry of Environment.

ME, 2019a, Continuous efforts to eradicate and expedite the occurrence of illegal waste, 2019.12.03 http://www.me.go.kr/home/web/ board/read.do?boardMasterId=1\&boardId=1124670\&menuId= 286 Accessed 25 April 2021

ME, 2019b, White paper of environment, Ministry of Environment.

ME, 2019c, Construction waste recycling promotion act, No. 16317, Ministry of Environment.

MOLIT, 2017, Quality standard of recycled aggregate, Ministry of Land, Infrastructure and Transport.

MOLIT, 2020, Regulations on the mandatory use of recycled aggregates for construction projects, Ministry of Land, Infrastructure and Transport.

MOLIT, 2021, Annual status of aggregate extraction, Ministry of Land, Infrastructure and Transport. http://www.index.go.kr/potal/main/ EachDtlPageDetail.do?idx_cd=1223. Accessed 25 Apr 2021

$\mathrm{Na} C-\mathrm{S}$ (2018) Plan for use invigoration of recycled aggregate-in terms of producers. J Rec Const Resources 13(2):25-32

OECD (2015) Population density and ageing, in sectoral and economic trends of environmental significance. OECD Publishing, Paris,. https://doi.org/10.1787/9789264235199-table78-en
Oh J-H, Kim M-S, Shin H-D, Min J-W (2008) Recent status on the recycling of construction waste and research trends-the current situation of recycling technology for waste resources in Korea (4)-. J Korean Inst Resour Recycl 17:16-29

Park J-S, Song T-H, Choi D-H (2013) Applicable building range for the introduction of the building separation and dismantling system. J Rec Const Resources 1:189-196

Park S-W (2017) Improvement of national waste statistics. J Korea Soc Waste Manag. https://doi.org/10.9786/kswm.2017.34.5.431

Silva RV, de Brito J, Dhir RK (2017) Availability and processing of recycled aggregates within the construction and demolition supply chain: a review. J Clean Prod 143:598-614. https://doi.org/10. 1016/j.jclepro.2016.12.070

SLC, 2019, 2018 Sudokwon landfill statistics yearbook, Sudokwon Landfill Site Management Corporation.

Song TH, Park JS (2016) Development and performance evaluation of single process separating and sorting pilot for mixed construction waste. J Rec Const Resources. 4:371-378

Song T-H, Seong J-U (2017) Comparison of the construction waste generated by the project and the estimation of the waste generation unit. J Rec Const Resources 5(4):427-434

Tam VWY, Tam CM (2007) Assessment of durability of recycled aggregate concrete produced by two-stage mixing approach. J Mater Sci. https://doi.org/10.1007/s10853-006-0379-y

Tam VWY, Soomro M, Evangelista ACJ (2018) A review of recycled aggregate in concrete applications (2000-2017). Constr Build Mater 172:272-292. https://doi.org/10.1016/j.conbuildmat.2018. 03.240

Yang S, Lim Y (2018) Mechanical strength and drying shrinkage properties of RCA concretes produced from old railway concrete sleepers using by a modified EMV method. Constr Build Mater 185:499-507. https://doi.org/10.1016/j.conbuildmat.2018.07.074

Yang W-S, Park J-K, Park S-W, Seo Y-C (2015) Past, present and future of waste management in Korea. J Mater Cycles Waste Manag. https://doi.org/10.1007/s10163-014-0301-7

Yeheyis M, Hewage K, Alam MS, Eskicioglu C, Sadiq R (2013) An overview of construction and demolition waste management in Canada: a lifecycle analysis approach to sustainability. Clean Techn Environ Policy. https://doi.org/10.1007/s10098-012-0481-6

Yu M-Y (2015) Systematic complement for practical usage of recycled aggregates concrete. Mag RCR 10:28-32

Wi J-H, Hong S-Y, Lee D-S, Park S-W, Choi H-S (2011) Evaluation of compaction and thermal characteristics of recycled aggregates for backfilling power transmission pipeline. J Korean Geotech Soc. https://doi.org/10.7843/kgs.2011.27.7.017

Publisher's Note Springer Nature remains neutral with regard to jurisdictional claims in published maps and institutional affiliations. 